\title{
Entrepreneurship as a Key to Anthropo-Social and Economic Development in Rwanda: Case of Young Female Sex Workers Assisted by PCLS in Byumba City, Byumba Sector in Gicumbi District (2016-2017)
}

\author{
Father Dr. Lucien HAKIZIMANA ${ }^{1, *}$, Alexandre NTEZIMANA ${ }^{2}$, Marthe UWINGENZI ${ }^{3}$ \\ 1, 2, 3 University of Technology and Arts of Byumba (UTAB), Rwanda
}

*Corresponding Author: Father Dr. Lucien HAKIZIMANA, University of Technology and Arts of Byumba (UTAB), Rwanda

\begin{abstract}
Prostitution of young female fueled by poverty is a crucial problem which affects their anthroposocial and economic development. Young female sex workers from Byumba city face many problems. To overcome these problems, PCLS started a project to enhance entrepreneurship skills of young female sex workers from Byumba city. This study is entitled "entrepreneurship as a key to anthropo-social and economic development, case of young female sex workers assisted by PCLS in Byumba city, Byumba sector in Gicumbi district (2016-2017). Its objective is to point out the contribution of entrepreneurship to the anthropo-social and economic development of YFSW.
\end{abstract}

In carrying out this study, the researchers have used qualitative, quantitative methods. To collect data, researchers used techniques which include questionnaire, interview, observation and documentation. The sample size was composed by 57 respondents selected randomly from 192 young female sex workers from Byumba city assisted by PCLS and researchers added 4 interviewees composed by one (1) in charge of social affairs of Byumba Sector, and three (3) PCLS staff.

Findings show that PCLS provided assistance to YFSW which include training (100\%), creation and implementation of GSLA system (100\%) counseling which helped beneficiaries to cope with psychosocial problems (100\%); creation of HR groups (100\%), while community mobilization activities represent $100 \%$. Other assistance included advocacy and network with other stakeholders on how they could found other support (100\%), regular visits (100\%) and legal assistance (59.6\%).

As results, young female sex workers entrepreneurs (100\%) acquired the capacity for self paying Mutual Health Insurance and (100\%) said that they were no more isolated for having adhered in associations and clubs. In addition, (86.0\%) said that they can rent business and resident houses, whereas $26.3 \%$ they are paying their schools fees in VTCs.

Keywords: Entrepreneurship, Young Female Sex Workers, Byumba City, Anthropo-Social and Economic Development, Contribution, PCLS.

Acronyms: AOF: Agriculture Organic Farming, DV: Domestic Violence, FP: Family Planning, GBV: Gender Based Violence, GSLA: Groups Savings and Loans Association, HBC: Home Based Care, HR: Human Right, IGA: Income Generating Activities, LIW: Low-Income Women, PCLS: Programme Communautaire de Lutte contre le SIDA, PLW HIV/AIDS: People Living With HIV/AIDS, STDs: Sexually Transmitted Diseases, VTCs: Vocational Training Centers, YFSW: Young Female Sex Workers

\section{INTRODUCTION}

Entrepreneurship has been broadly defined as new business creation ${ }^{1}$, and entrepreneurs were taken by many researchers to refer to business owners who notice opportunities and decide how to mobilize the resources necessary to produce new and improved goods and services and run their own

\footnotetext{
${ }^{1}$ Gareth R. Jones, Jennifer M. George (2015), Essentials of Contemporary Management, $6{ }^{\text {th }}$ Edition, New York, McGraw-Hill Education, 287.
} 
businesses $^{2}$. This definition is used by prominent entrepreneurship research organizations and many entrepreneurship researchers. Entrepreneurship in the context of this research regards prostitutes called technically female sex workers with their achievements in job creation with the purpose of increasing different drivers of development, productivity, innovation and employment, and it is widely accepted as a key of anthropo-social and economic development. Transforming ideas into anthropo-social and economic opportunities is the decisive issue of entrepreneurship. History shows that progress has been significantly advanced by pragmatic people who are entrepreneurial and innovative, able to exploit opportunities and willing to take risks ${ }^{3}$.

High levels of poverty combined with too slow economic growth have forced some young people to be part of female sex workers even though this is not necessarily the only one reason why they adopt this bad behavior. Entrepreneurship should contribute significantly to their behavior change anthropologically, socially and can contribute to their economic development. With skills in entrepreneurship provided to these YFSW by PCLS, they find economic opportunities in microenterprises as business owners and employees.

Skills development, as well as the promotion of entrepreneurship that display entrepreneurial motivation, have been already fostered by PCLS initiatives to help YFSW to respond to their needs and then slow by slow to end with the prostitution overcoming social barriers ${ }^{4}$. Thus, in this study it is thought to assess the contribution of young female sex workers' entrepreneurship in their anthroposocial and economic development.

\section{ReSEARCH MeThodology}

According to bailey ${ }^{5}$, methodology means the philosophy of research process, body of practices, procedures, and rules used by those who work in a discipline or engage in an inquiry. In our research we used different methods such as quantitative and qualitative methods.

This research is quantitative because it includes designs, techniques and measures that produce discrete, numerical or quantifiable data ${ }^{6}$. The information was gathered through questionnaires whereby the information collected from the respondents through the use of questions was analyzed by the use of simple tabulation and calculation of percentages so as to depict the magnitude of responses by the target population. The quantitative method served us with a clear scope of the problems of YFSW and different activities carried out by PCLS on rehabilitation of YFSW. As the study of the whole Rwandan society could not be easy, we chose a case study of Byumba city because it is where you can find most YFSW from surrounding rural areas.

We used also qualitative method. According to $\mathrm{Gay}^{7}$ qualitative research is a method of analysis, working in many different academic disciplines, usually in the social sciences but also in other research and further contexts. In this research, qualitative research aimed to gather and to analyze deeply young female sex workers' behaviors and the reasons that direct such behaviors.

\subsection{Study Population and Sample Size}

Our research concerns entrepreneurship as key to the anthrop-social and economic development of young female sex workers; case study of Byumba city (2016-2017). The whole population is 192 YFSW. The sample in this research was drawn by using the Bouchard Formula. In this formula, the author suggest that if the population is greater than five hundred, the collected sample is eighty one (81) individuals whereas for the population less than five hundred, the sample will be calculated by the following formula:

\footnotetext{
${ }^{2}$ Gareth R. Jones, Jennifer M. George (2015), Essentials of Contemporary Management, $6{ }^{\text {th }}$ Edition, New York, McGraw-Hill Education, 287.

3 Henry, C., Hill, F. and Leitch, C. (2003). Entrepreneurship Education and Training, p35

${ }^{4}$ Gareth R. Jones, Jennifer M. George (2015), Essentials of Contemporary Management, $6{ }^{\text {th }}$ Edition, New York, McGraw-Hill Education, 97.

${ }^{5}$ Bailey Kenneth D. (1978), Methods of social research, A division of McMillan publishing inc. New York: 26.

${ }^{6}$ GAY, L.R. (2000). Educational research, New Jersey, Prentice Hall. Inc.: 40.

${ }^{7}$ GAY, L.R. (2000). Educational research, New Jersey, Prentice Hall. Inc.:39.
} 
The formula of Bouchard, A. ${ }^{8}$, used to choose the sample size of our research is $n_{c}=N:(1+n: N)$

$\mathrm{N}=$ the number of the whole population

$\mathrm{n}_{\mathrm{c}}=$ the sample to be examined

$\mathrm{n}=81$

In developing that formula we find: $\mathrm{N}:\left(1+\frac{n}{N}\right)=(\mathrm{N} \times \mathrm{n}):(1+(\mathrm{N} \times \mathrm{n}: \mathrm{N}+\mathrm{n}))=\left(\frac{N \times n}{N+n}\right)$

So, the size of sample study is chosen according to that formula of Alain Bouchard, which is: $\left(\frac{N \times n}{N+n}\right)$

Our research is conducted on 192 YFSW in Byumba city.

The application of the formula shows us the following results:

$\mathrm{N}=192$

$\mathrm{n}=81$ as the size of the random sample

Thus, $\left.\left(\frac{N \times n}{N+n}\right)=\frac{192 \times 81}{192+81}\right)=\frac{15552}{273}=56.9 \approx 57$ individuals.

Our research is conducted on a sample of 57 young female sex workers entrepreneurs.

\subsection{Sampling Technique}

Sampling technique refers to the method used to select a sample in population under a study. In this study, we used the random sampling and purposive sampling. According to Marlow Christine ${ }^{9}$, random sampling is a procedure that ensures that each element in the population has an equal chance of being selected. In this study, we used random sampling to select 57 among a list of 192 YFSW by picking up from the box any number from 192 mixed numbers written on a piece of paper. The names corresponding to the chosen numbers constitute our sample population.

Furthermore, the researchers used the purposive sampling technique. This enabled him to pick the respondents who could meet the purpose of the study. Kenneth D. Bailey ${ }^{10}$ explained purposive sampling as a method of sampling where the researcher uses his or her own judgment about which he chooses and picks only those respondents who can best meet the purpose of the study. In this study, we used the purposive sampling technique to select key informants. We selected one (1) in charge of social affair in Byumba Sector and three (3) PCLS staff, as we judged them as having liable information needed in our study related to contribution of entrepreneurship to anthropo-social and economic development.

\section{RESUlTS PRESENTATION, ANALYSIS AND INTERPRETATION}

Before intervention of PCLS, young female sex workers in Byumba city faced different problems including violence. Respondents were asked to identify main forms of violence against them. Results are shown in the following table.

\subsection{Forms of Violence Faced by YFSW in Byumba City}

\begin{tabular}{|l|l|l|}
\hline \multicolumn{1}{|c|}{ Form of violence } & \multicolumn{1}{c|}{ Frequencies $(\mathbf{N}=\mathbf{5 7})$} & Percentages (\%) \\
\hline Physical violence & 53 & 92.9 \\
\hline Economic violence & 45 & 78.9 \\
\hline Sexual violence & 41 & 71.9 \\
\hline Psychological violence & 37 & 64.9 \\
\hline
\end{tabular}

Source: Results from respondents, August 2017

\footnotetext{
${ }^{8}$ BOUCHARD A. (1989), Méthodologie de la recherche, Dalloz, Paris : 73.

9 Marlow Christine. (2001). Research Methods for Generalist Social Work. Belmont, Wadsworth/Thomson learning, USA: 43.

${ }^{10}$ Bailey, K. D. (1994). Methods of social research.New York: Free press:83.
} 
As displayed by the above table, physical violence is in the first position and is expressed by 53 out of 57 , that is, $92.9 \%$ of respondents, while economic violence is at the second position as asserted by 45 out of 57, that is, $78.9 \%$ of respondents. Sexual violence comes at the third position with 41 out of 57, that is, $71.9 \%$ of respondents and lastly psychological violence comes at the $4^{\text {th }}$ position with $64.9 \%$.

Researcher wanted to know other problems apart from violence faced by young female sex workers. The following table summarizes different answers given by respondents.

\subsection{Anthropo-Social and Economic Problems Faced by Young Female Sex Workers}

\begin{tabular}{|l|l|l|}
\hline \multicolumn{1}{|c|}{ Consequences } & Frequencies (N=57) & \multicolumn{1}{c|}{ Percentages (\%) } \\
\hline Poverty & 43 & 75.4 \\
\hline Economic dependence & 30 & 52.6 \\
\hline Trauma & 41 & 71.9 \\
\hline Feelings of depression and isolation & 26 & 45.6 \\
\hline STDs & 33 & 57.8 \\
\hline Loss of sexual desire & 32 & 56.1 \\
\hline
\end{tabular}

Source: Results from respondents, August 2017

According to the results from the above table, the majority of the respondents $75.4 \%$ said that the YFSW lived in poverty and $71.9 \%$ had psychological trauma. In addition, $45.6 \%$ of respondents feel depressed and isolated while $57.8 \%$ of respondents said that suffer from STDs; while $56.1 \%$ asserted that they lost sexual desire. And 52.6\% were economically dependent.

\subsubsection{Contribution of PCLS in Rehabilitation YFSW}

This item points out different activities carried out by PCLS and its positive impact in improving the lives of young female sex workers. The results of findings are presented in the following table.

\subsection{Activities carried out by PCLS in the Rehabilitation of YFSW}

\begin{tabular}{|l|l|l|}
\hline \multicolumn{1}{|c|}{ Support services } & Frequencies (N=57) & \multicolumn{1}{c|}{ Percentages (\%) } \\
\hline Training in entrepreneurship skills & 57 & 100 \\
\hline Creation and Monitoring of GSLA & 57 & 100 \\
\hline Paiement of Mutual Health Insurance & 57 & 100 \\
\hline Counselling & 48 & 84.2 \\
\hline Paying visits & 57 & 100 \\
\hline Community mobilization & 57 & 100 \\
\hline Advocacy & 57 & 100 \\
\hline Legal Assistance & 34 & 59.6 \\
\hline
\end{tabular}

Source: Results from respondents, August 2017

The table indicates the main activities done by PCLS for beneficiaries in order to rehabilitate them and to reinforce their capacities. The major activities include training in entrepreneurship skills representing $100 \%$ and creation and monitoring of GSLA system representing 100\%. In addition, payment of mutual health insurance represents $100 \%$, while counseling which helped beneficiaries to cope with psychosocial problems related to their situation represents $84.2 \%$. Community mobilization activities represent $100 \%$. Besides, $100 \%$ of respondents asserted that PCLS assisted them in paying regular visits whereas 100\% said that PCLS assisted them in Advocacy. Finally, 59.6\% of respondents benefited from Legal assistance.

In this perspective, the in charge of social affairs asserted that PCLS played a big role in improving their living conditions ${ }^{11}$. Furthermore, interviewees said that beneficiaries received training in different topic such as human right, laws, FP, GBV, HIV/AIDS/STDs, Drug abuse prevention, strategies for poverty reduction, peer education, home-based care and training on how they can start small business that will allow them to reduce poverty.

\subsection{Strategies Used by PCLS in Promoting Entrepreneurship Skills of YFSW}

Different strategies on this field are used as it is highlighted in the following table:

\footnotetext{
${ }^{11}$ http://en.wikipedia.org/wiki/ Catholic Church, retrieved on $2^{\text {nd }}$ August, 2017.
} 
Entrepreneurship as a Key to Anthropo-Social and Economic Development in Rwanda: Case of Young Female Sex Workers Assisted by PCLS in Byumba City, Byumba Sector in Gicumbi District (2016-2017)

\begin{tabular}{|l|l|l|}
\hline \multicolumn{1}{|c|}{ Strategies } & Frequencies (N=57) & Percentages (\%) \\
\hline Meeting & 57 & 100 \\
\hline Peer education & 57 & 100 \\
\hline Sensitization & 57 & 100 \\
\hline Magnet theatre presentation & 57 & 100 \\
\hline Focus group discussion & 57 & 100 \\
\hline
\end{tabular}

\subsection{Anthropo-Social Outcome of the Assistance Provided by PCLS in Rehabilitation of YFSW}

In this study, the researchers wanted to know whether and how different strategies used and the activities carried out by PCLS to assist YFSW have generated a positive impact.

\subsubsection{Adherence of YFSW in Association and Clubs}

In this study, researchers wanted to know how PCLS helps YFSW in resolving their anthropo-social and economic problems. The results are presented in the table ahead.

\subsubsection{Participation in Associations and Clubs}

\begin{tabular}{|l|l|l|}
\hline \multicolumn{1}{|c|}{ Cooperative/association } & Frequencies(N=57) & \multicolumn{1}{c|}{ Percentages (\%) } \\
\hline GSLA & 36 & 63.1 \\
\hline LIW & 25 & 43.8 \\
\hline Human rights and DV/GBV Clubs & 13 & 22.8 \\
\hline Community volunteers association & 12 & 21.05 \\
\hline PLW HIV/AIDS & 12 & 20.3 \\
\hline
\end{tabular}

Source: Results from respondents, August 2017

As displayed in the table, (63.1\%) of all respondents were members of GSLA and $43.8 \%$ were members of LIW cluster. In addition, respondents who represent $22.8 \%$ informed that they adhered to human right promotion and DV/GBV prevention clubs while others, who represent $21.05 \%$ of all respondents, have adhered to the community volunteers association. Lastly, $21.05 \%$ of the total sample was members of HIV/AIDS clubs.

\subsection{Economic Development of YFSW}

In this study, the researchers wanted to assess whether the assistance provided by PCLS contributed to the improvement of economic development of YFSW from Byumba city.

The table below summarizes the respondents' answers.

\subsubsection{Activities Carried Out by YFSW}

\begin{tabular}{|l|l|l|}
\hline \multicolumn{1}{|c|}{ Activity } & No of respondents(N=57) & Percentages \\
\hline Investment in agricultural activities & 18 & 31.5 \\
\hline Purchasing livestock & 21 & 36.8 \\
\hline Buying cattle & 27 & 47.3 \\
\hline Carrying out small business & 19 & 33.3 \\
\hline
\end{tabular}

Source: Results from respondents, August 2017

This table shows that $33.3 \%$ of respondents were able to start their businesses and increase the business activities, while $31.5 \%$ have invested money in agricultural activities. In addition, while 36.8 of respondents affirmed that they are able to purchase livestock, $47.3 \%$ of respondents affirmed that they use their loans by purchasing cattle.

According to in charge of social affairs interviewed, animals are viewed as saving banks, since the livestock represent significant capital that can be easily and quickly converted into money or food in times of need, and in case of sudden expenditures for illness, weddings, deaths, and other ceremonies. Therefore, this reveals that in the vast majority of young female sex workers entrepreneurs have the ability to raise animals is considered as the optimal saving strategy before savings and credit systems.

\subsubsection{Entrepreneurship Impact on Anthropo-Social and Economic Development of Young Female Sex Workers Entrepreneurs}

In this study, the researchers wanted to know whether enterprises of young female sex workers entrepreneurs contributed to their anthropo-social and economic development. The results are summarized in the next table. 
Entrepreneurship as a Key to Anthropo-Social and Economic Development in Rwanda: Case of Young Female Sex Workers Assisted by PCLS in Byumba City, Byumba Sector in Gicumbi District (2016-2017)

Table1. Improvement of social living conditions for YFSW

\begin{tabular}{|l|l|l|}
\hline \multicolumn{1}{|c|}{ Outcome } & \multicolumn{1}{|c|}{ Frequencies $(\mathbf{N = 5 7 )}$} & \multicolumn{1}{|c|}{ Percentages (\%) } \\
\hline Capacity for Self payment of Health insurance & 57 & 100 \\
\hline Busines and resident house renting & 49 & 85.9 \\
\hline Paying their schools fees in VTCs & 15 & 26.3 \\
\hline Savings and credits & 57 & 100 \\
\hline
\end{tabular}

Source: Results from respondents, August 2017

As it is displayed by the previous table, $100 \%$ of respondents reported to have been able to pay by themselves Mutual Health Insurance and for other family members while $85.9 \%$ of respondents said that they rented business and resident houses. In addition, other respondents $26.3 \%$ said that they paid their schools fees in VTCs. Furthermore, 100\% said that after they undertook their small businesses, they have bank accounts to facilitate savings and credits.

\section{DisCUSSION OF FINDINGS}

After presenting data in tables, it is worthwhile making the data speak by discussing on the results given by different respondents. Data to be discussed deal with the problems of young female sex workers, the contribution of PCLS in improving their anthropo-social and economic situation.

\subsection{Types of Problems Faced by YFSW}

Concerning types of violence presented, $92.9 \%$ of respondents have been physically abused. According to respondents, as men come to them after getting drunk they sometimes refuse to pay and if YFSW ask for the payment they are beaten.

$78,9 \%$ of respondents pointed out the economic violence which is expressed through non assistance by the family. According to respondents, economic violence occurs when the abuser do not pay and go while they have fixed the price.

The rape and sexual abuse are represented by $71.9 \%$ of respondents. However the rape of the YFSW by their partners happen when they come drunk and without money.

Psychological violence comes in $4^{\text {th }}$ position with $64.9 \%$ of respondents. This form of violence can be verbal or non-verbal. According to respondents, this form includes discrimination of YFSW by the community.

Concerning other problems faced by YFSW, respondents mentioned the following: living in poverty; being discriminated by the community.

Poor young female sex workers lack of control over their sexuality that makes them more vulnerable to HIV/AIDS/ STDs.

\subsection{Overcoming these Problems by Entrepreneurship Skills}

To overcome these problems PCLS provided assistance to them through different activities including training in different topic such as human right, STDs, FP, GBV, Drug abuse prevention, HBC and AOF methodology, Guidance and Counseling, Strategies for poverty reduction... PCLS also provided training on initiation to small business (Entrepreneurship) what allowed them to improve their anthropo-social and economic situation.

In fact, a core of PCLS economic strengthening methodology is to provide training to all GSLA members in entrepreneurship, savings procedures and loaning procedures once the group has formed. The overall outcome, as asserted by respondents $(75,4 \%)$, is the reduction of poverty and prostitution.

In addition, as revealed by the PCLS staff, GSLA system has been created and implemented in order to improve factors that increase female economic independence and to reduce of the number of YFSW.

According to in charge of social affairs, the informal financial system known as GSLA helped YFSW to enhance and improve their anthropo-social and economic development. He added that GSLA contributed as informal finance systems towards poverty reduction among the vulnerable people especially YFSW. 
In an interview, the in charge of social affairs told the researchers that, PCLS organized meetings, campaigns with specific topic and magnet theatre presentations in order to sensitize the population on promotion of human and woman rights, poverty reduction, and to encourage YFSW to become entrepreneurs.

\subsection{Contribution of Entrepreneurship to Anthropo-Social and Economic Development of Young Women Sex Workers Entrepreneurs}

Concerning the improvement of anthropo-social and economic development of young women sex workers entrepreneurs, all respondents (100\%) reported that entrepreneurship skills contributed to income increasing and YFSW are capable to pay for themselves Mutual Health Insurance, contributed to autonomy and self-care.

The in charge of social affairs asserted that before PCLS and becoming entrepreneurs, they did not have health insurance where the local authorities had big problem with them. He added that when they got sick, they did not have a chance to access medical services. But, after becoming entrepreneurs the situation has been improved.

Other respondents (36.8\%) declared that they have been able to purchase livestock. Moreover, $85.9 \%$ are able to pay rent for resident and business houses. 26.3\% pay themselves VTC fees in order to learn a new career like tailoring, cooking, hairdressing so that they can create new businesses. $100 \%$ have bank account and it is used to save their money after selling their products. All respondents have benefits from small business and other IGA.

\section{CONCLUSION}

This study has shown that entrepreneurship provides a great opportunity, not only for addressing anthropo-social economic problems of young female entrepreneurs, but also to address other issues of common concern of the community. 100\% of YFSW attested that after creating their own enterprises their lives changed.

In fact, respondents corroborated that the anthropo-social and economic problems of young female sex workers entrepreneurs (100\%) have reduced because of different IGA initiated thanks to PCLS. From the results of our findings, anthropo-social and economic level of young female sex workers entrepreneurs have been improved considerably and this confirm that entrepreneurship is the key to anthropo-social and economic development.

The findings of the study have shown that with small enterprises YFSW improved their lives. 100\% of respondents reported that they are paying by themselves Mutual Health Insurance and for other family members, $86 \%$ of respondents said that they rented business and resident houses, $26.3 \%$ said that they paid their schools fees in VTCs, $100 \%$ said that since they undertook their small businesses, they have bank accounts to facilitate savings and credits.

Young Female sex workers entrepreneurs in Byumba city have contributed to increase financial income of household and to improve economic conditions and social status. They play a very important role in social change of the entrepreneurs' life in general. Openness to experience and taking the risks have brought interests ${ }^{12}$ which contributed to anthropo-social and economic change.

However, even if young female sex workers entrepreneurs' activities have increased financially income of young female sex workers entrepreneurs, they are still facing the challenges of high government taxes and lack of investment capital for some new businesses.

\section{REFERENCES}

[1] Ács, Z.J., Desai, S. and Hessels, J. (2008) : "Entrepreneurship, economic development and institutions", Small Business Economics, 31: 219-234.

[2] Andersson, P. (2008). "Happiness and Health: Well-Being among the Self-Employed", Journal of SocioEconomics, 37, 213-236.

[3] Bailey, K. D. (1994): Methods of social research.New York: Free press.

${ }^{12}$ Gareth R. Jones, Jennifer M. George (2015), Essentials of Contemporary Management, $6^{\text {th }}$ Edition, New York, McGraw-Hill Education, 49. 
Entrepreneurship as a Key to Anthropo-Social and Economic Development in Rwanda: Case of Young Female Sex Workers Assisted by PCLS in Byumba City, Byumba Sector in Gicumbi District (2016-2017)

[4] Baumol, W.J. (1990) : "Entrepreneurship: Productive, Unproductive and Destructive", The Journal of Political Economy 98(5): 893-921.

[5] Benz, M. and Frey, B.S. (2004) : "Being Independent Raises Happiness at Work", Swedish Economic Policy Review, 11, 95-134.

[6] Block, J. and Koellinger, P. (2009) : I Can’t get No Satisfaction -Necessity Entrepreneurship and Procedural Utility, Kyklos.

[7] Bouchard A. (1989) : Méthodologie de la recherche, Dalloz, Paris.

[8] Brück, T., Naudé, W.A. and Verwimp, P. (2011) : "Small Business, Entrepreneurship and Violent Conflict in Developing Countries", Journal of Small Business and Entrepreneurship, 24 (2): 161-178.

[9] Bruton, G.D., Ahlstrom, D. and Obloj, K. (2008) : "Entrepreneurship in Emerging Economies: Where Are We Today and Where Should the Research Go in the Future", Entrepreneurship Theory and Practice, January : 1-14.

[10] Ciccone, A. and Matsuyama, K. (1996) : "Start-up Costs and Pecuniary Externalities as Barriers to Economic Development", Journal of Development Economics, 4: 33-59.

[11] Creswell J. W. (2003): Research design: A qualitative, quantitative, and mixed method approaches. Thousand Oaks, CA: Sage Publications.

[12] De Meza, D. and Webb, D. (1987) : "Too Much Investment: A Problem of Assymetric Information", Quarterly Journal of Economics, 102(2): 281-92.

[13] Deketel J. M, (1996): Research documentation, London: UK.

[14] Evans, D.S., and B. Jovanovic (1989) : "As Estimated Model of Entrepreneurial Choice Under Liquidity Constraints", Journal of Political Economy 97(4): 808-27.

[15] Gareth R. Jones, Jennifer M. George (2015) : Essentials of Contemporary Management, $6^{\text {th }}$ Edition, New York, McGraw-Hill Education.

[16] Gay, L.R. (2000): Educational research, New Jersey: Prentice Hall. Inc..

[17] Gollin, D. (2008) : "Nobody's business but my own: Self-employment and small enterprise in economic development", Journal of Monetary Economics, 55 (2) : 219-233.

[18] Gries, T. and Naudé, W.A. (2010) : "Entrepreneurship and Structural Economic Transformation", Small Business Economics Journal, 34 (1): 13 - 29.

[19] Hausmann, R. and Rodrik, D. (2003) : "Economic Development as Self-discovery", Journal of Development Economics, 72(2): 603-33.

[20] Horrell, S. And Krishnan, P. (2007) : "Poverty and Productivity in Female-Headed Households in Zimbabwe", Journal of Development Studies, 43 (8): 1351-1380.

[21] http://en.wikipedia.org/wiki/ Catholic Church, retrieved on $2^{\text {nd }}$ August, 2017.

[22] Langowitz, N. and Minniti, M. (2007) : "The Entrepreneurial Propensity of Women", Entrepreneurship Theory and Practice, 31 (3): 341-365.

[23] Lewis, W.A. (1954): "Economic Development with Unlimited Supplies of Labour", The Manchester School, 28(2): 139-191.

[24] Marlow Christine. (2001): Research Methods for Generalist Social Work: Belmont, Wadsworth/Thomson learning: USA.

[25] Nachmias D. et al. (1976): Research methods in social sciences, St. Martins, press: New York.

[26] Neuman W. Lawrence. (2011): Social research methods: Qualitative and quantitative approaches. $6^{\text {th }}$ edition, Boston: Pearson International Edition.

Citation: Father Dr. Lucien HAKIZIMANA, Alexandre NTEZIMANA, Marthe UWINGENZI. "Entrepreneurship as a Key to Anthropo-Social and Economic Development in Rwanda: Case of Young Female Sex Workers Assisted by PCLS in Byumba City, Byumba Sector in Gicumbi District (2016-2017)." International Journal of Research in Sociology and Anthropology (IJRSA), vol 4, no. 1, 2018, pp. 16-23. doi:http://dx.doi.org/10.20431/2454-8677.0401003.

Copyright: (C) 2018 Authors. This is an open-access article distributed under the terms of the Creative Commons Attribution License, which permits unrestricted use, distribution, and reproduction in any medium, provided the original author and source are credited. 